\title{
11. DATA REPORT: GEOCHEMISTRY OF BASALTS AND GLASSES FROM THE EAST PACIFIC RISE AXIS ZONE AT $9^{\circ} 30.45^{\prime} \mathrm{N}$, LEG $142^{1}$
}

\author{
A. Artamonov, ${ }^{2}$ N. Sushchevskaya,${ }^{3}$ B. Zolotarev, ${ }^{2}$ G. Kashinzev, ${ }^{4}$ and V. Kurnosov ${ }^{2}$
}

\begin{abstract}
Petrographic and geochemical data from East Pacific Rise basalts cored at Ocean Drilling Program Site 864 show that the rocks are practically unaltered normal mid-ocean-ridge basalts (N-MORB). The analyzed glasses from four samples were practically identical in composition, suggesting a common source for corresponding lava flows.
\end{abstract}

\section{INTRODUCTION}

During Ocean Drilling Program Leg 142, Site 864 was drilled at the East Pacific Rise (EPR) axial zone, $9^{\circ} 30.85^{\prime}, 104^{\circ} 14.66^{\prime}$. The site is south of the Clipperton transform fault and north of an overlapping spreading center. Three holes were drilled at Site 864 and cores were recovered from two holes.

\section{METHODS}

Igneous whole rocks and glasses were studied in thin sections to determine mineralogy and texture.

Rare earth elements (REE) in the basalts were determined by radiochemical neutron activation in the Analytical Center of the Geological Institute, Russian Academy of Sciences. 100-mg samples were irradiated together with a standard by a thermal neutron flux of $1.2 \times 10^{13} \mathrm{n} / \mathrm{cm}^{2} \times \mathrm{s}$ during $20 \mathrm{hr}$. REE fractions were separated by radiochemical method. Gamma-spectrometry determination REE was done with a coaxial $\mathrm{Ge}(\mathrm{Li})$-detector. The accuracy of the analyses ( $1 \sigma$ errors) for individual elements is: $\pm 3 \%-5 \%$ for $\mathrm{La}, \mathrm{Sm}, \mathrm{Eu}$, and $\mathrm{Yb}$ and $\pm 5 \%-7 \%$ for $\mathrm{Ce}, \mathrm{Tb}$, and $\pm 10 \%$ for Nd. The accuracy of the determination has been checked against USGS BHVO-1 standard (Gladney and Roelandts, 1988).

All analyses of major and trace elements in the glasses were made at the Central Analytical Laboratory of the Geochemistry and Analytical Chemistry Institute, Russian Academy of Science.

The glass compositions were determined by microprobe analysis with a Camebax-Microbeam analyzer and four vertical spectrometers (X-ray angle of emergence $40^{\circ}$; probe diameter, $\sim 1 \mu \mathrm{m}$ ). The error was not more than $\pm 1.5 \%$ relative, sensitivity 0.01 mass percent.

Fragments of pure glass $(0.5-0.25 \mathrm{~mm})$ separated under the binocular microscope were used for the analyses. A special method was developed to determine the glass compositions. Silicate analysis for 10 elements was perfomed with an accelerating potential of $15 \mathrm{kV}$ and probe current of $30 \mathrm{nA}$ (the automatic parameter adjustment and monitoring enabled us to reproduce the analysis conditions with nec-

\footnotetext{
${ }^{1}$ Batiza, R., Storms, M.A., and Allan, J.F. (Eds.), 1995. Proc. ODP, Sci. Results, 142: College Station, TX (Ocean Drilling Program).

${ }_{3}^{2}$ Geological Institute, Pyzhevsky Per. 7, Moscow 109017, Russia.

${ }^{3}$ Geochemistry and Analytical Chemistry Institute, Kosygin St. 19, Moscow 117975 , Russia.

${ }^{4}$ Institute of Oceanology, Krasikov St. 23, Moscow 117218, Russia.
}

essary accuracy). We recorded the corresponding $\mathrm{K}$ series for the elements.

To reduce the beam damage, all the measurements were made with scanning over an area of $5 \times 5 \mu \mathrm{m}$ (scan time per frame $0.2 \mathrm{sec}$ ). The X-ray intensities were measured at three arbitrarily selected points in each of three grains. The composition was thus determined at the mean of nine measurements. The reproducibility was $\pm 2 \%$ relative on the major elements having contents over 5 mass percent. To check the accuracy, a control measurement was made on a reference standard after every 10-15 measurements, from which we corrected the deviations in the element contents from the recommended values. That standard for the major elements was chosen as the international standard VG-2 (USNM-111240/52) for natural basalt glass (Melson et al., 1977).

Analyses of $\mathrm{V}, \mathrm{Cr}, \mathrm{Ni}, \mathrm{Cu}, \mathrm{Zn}, \mathrm{Sc}, \mathrm{Sr}, \mathrm{Y}, \mathrm{Zr}$, and $\mathrm{Ba}$ in the glasses were performed by atomic emission spectrometry with inductively coupled plasma (ICP AES). Conditions were found for determination of trace elements by ICP AES in solution containing high concentrations of metal cations $(3-6 \mathrm{mg} / \mathrm{ml})$. To reduce matrix interferences, the reference solutions were prepared using a synthetic matrix with a composition of average rock. Optimal plasma zones were selected for determining trace elements. Programs were obtained for the analysis of 16 elements in rocks on an multichannel atomic emission spectrometer ICAP-9000 (Termo Jarrell ASP Corp. USA). A method is proposed for the analysis of rocks by ICP AES which, in combination with atomic absorption spectrometry (AAS) and flame AES. The metrical characteristics were estimated by analysis of standard reference samples of rocks. The relative standard deviation values were 0.005- 0.03 for major constituents and 0.01-0.1 for trace elements.

Analyses of $\mathrm{As}, \mathrm{Ag}$, and $\mathrm{Au}$ in the glasses were performed by AAS with atomic absorption electrotermic atomization (AAS ETA). Method detection limits for $\mathrm{As}, \mathrm{Au}$, and $\mathrm{Ag}$ are $0.5 \times 10^{-7} \%$. Relative standard deviation values were $0.02-0.05$.

Determination of REE in the glasses was performed by Neutron Activation Analysis. Two types of sample irradiation were employed. In the first case samples were irradiated with fast and thermal neutrons at a flux of $1.6 \times 10^{13} \mathrm{n} / \mathrm{cm}^{2} \times \mathrm{s}$ for $15 \mathrm{hr}$, and in the second case the samples were irradiated in cadmium filter for period of $80-100 \mathrm{hr}$. The sample masses were in the ranges $15-20 \mathrm{mg}$ and $50-60 \mathrm{mg}$, respectively.

Irradiated samples were analyzed at different time intervals to avoid interferences of radionuclides. Measurements were carried out using a $\mathrm{Ge}(\mathrm{Li})$ - and $\mathrm{Ge}$-detector, multichannel analyzer coupled with microprocessor. The gamma-spectra and elemental concentrations were evaluated using a special computer program. The accuracy of 
Table 1. Brief petrographic description of basalts (Unit 1), Site 864.

\begin{tabular}{|c|c|}
\hline $\begin{array}{l}\text { Core, section, } \\
\text { interval }(\mathrm{cm})\end{array}$ & Description \\
\hline $\begin{array}{l}142-864 \mathrm{~A}- \\
\quad 1 \mathrm{M}-2,0-35\end{array}$ & $\begin{array}{l}\text { Hyalobasalt, aphyric, practically noncrystallized, with sparse } \\
\text { microphenocrysts of plagioclase. Volcanic glass contains } \\
\text { section of dark, oxidized, partially devitrified glass with } \\
\text { crystallites of plagioclase and clinopyroxene. Single olivine } \\
\text { quench crystals and small drop-like inclusions of pyrite occur. } \\
\text { Hyalobasalt is fresh. }\end{array}$ \\
\hline $\begin{array}{l}142-864 \mathrm{~A}- \\
\quad \mathrm{IM}-3,0-35\end{array}$ & $\begin{array}{l}\text { Hyalobasalt, aphyric, weakly crystallized with vitrophyric } \\
\text { (subvariolitic in separate parts) texture. Groundmass consists } \\
\text { of isotropic brown partially devitrified volcanic glass, } \\
\text { crystallites of clinopyroxene, and isolated microlite of } \\
\text { plagioclase. Crystallites of clinopyroxene form radial-radiant } \\
\text { aggregates. Isolated prismatic microphenocrysts of plagioclase } \\
(<1 \mathrm{~mm}) \text { occur. Hyalobasalt is fresh. }\end{array}$ \\
\hline $\begin{array}{l}142-864 \mathrm{~A}- \\
\quad 1 \mathrm{M}-3,100-150\end{array}$ & $\begin{array}{l}\text { First thin section: Basalt, aphyric, weakly crystallized with } \\
\text { pilotaxitic texture. Microlites and laths of plagioclase and } \\
\text { clinopyroxene are } 80 \% \text { and dark isotropic glass composes } 20 \% \\
\text { of the rock. Microlites and laths are not oriented. Small } \\
\text { rounded forms of pyrite occur. The rock is almost fresh. In the } \\
\text { XRD there is a weak diffraction peak of smectite. } \\
\text { Second thin section: Basalt, aphyric, weakly crystallized with } \\
\text { isolated microphenocrysts of plagioclase. Texture of rock is } \\
\text { hyalopilitic. Plagioclase (up to } 0.5 \mathrm{~mm} \text { ) is labradorite }\left(\mathrm{An}_{62}\right) \text {. } \\
\text { Partially devitrifed volcanic glass consists of bunch-like } \\
\text { aggregates of microlites of clinopyroxene, laths of plagioclase, } \\
\text { ore dust, and isolated rhomboid olivine quench crystals. }\end{array}$ \\
\hline $\begin{array}{l}142-864 \mathrm{~A}- \\
1 \mathrm{M}-5,0-100\end{array}$ & $\begin{array}{l}\text { Hyalobasalt, aphyric, with practically isolated prismatic } \\
\text { microphenocrysts of plagioclase (up to } 0.5 \mathrm{~mm}) \text {. Texture of } \\
\text { rock is vitrophyric. Isolated vesicles occur. Volcanic glass } \\
\text { partially devitrified. Original isotropic glass has light-yellow } \\
\text { color. Devitrified glass occurring in same parts of rock has } \\
\text { black-brown color and consists of crystallites of plagioclase, } \\
\text { pyroxene, and sparse olivine quench crystals. In same parts of } \\
\text { the rock sparse glomerophyric aggregates of plagioclase occur. } \\
\text { Plagioclase is labradorite }\left(\mathrm{An}_{55}\right) \text {. Hyalobasalt is fresh. }\end{array}$ \\
\hline $\begin{array}{l}142-864 \mathrm{~A}- \\
1 \mathrm{M}-6,0-75\end{array}$ & $\begin{array}{l}\text { First thin section: Basalt, sparsely microplagiophyric, weakly } \\
\text { crystallized, weakly vesicular. Texture of groundmass } \\
\text { vitrophyric-variolitic. Groundmass is devitrified and is } \\
\text { represented by varioles (up to } 0.1 \mathrm{~mm} \text { ) filled by radially radiant } \\
\text { aggregates of clinopyroxene and plagioclase. In same parts of } \\
\text { the rock, original isotropic glass occurs. Sections of devitrified } \\
\text { glass include sparse phenocrysts of plagioclase. Basalt is fresh. } \\
\text { Second thin section: Hyalobasalt, aphyric, weakly crystallized } \\
\text { with isolated microcrysts of plagioclase. Texture of rock is } \\
\text { vitrophyric. Primary isotropic light-yellow volcanic glass } \\
\text { contains a part of partially devitrified, weakly anisotropic glass } \\
\text { with radially radiant aggregates of clinopyroxene and } \\
\text { plagioclase, and isolated olivine quench crystals. }\end{array}$ \\
\hline
\end{tabular}

the determination has been checked against interlaboratory standard (basalt 396B-15-2, 120-133 cm; Kirkpatrick et al., 1979).

\section{RESULTS}

On the ship, two lithologic units were identified based on geochemical and petrographic features. Unit 1 rocks are glassy, aphyric basalt. Unit 2 basalt occurs lower in the section and has more phenocrysts and crystalline groundmass. All rocks are practically fresh.
Table 3. Composition of glasses from Site 864 .

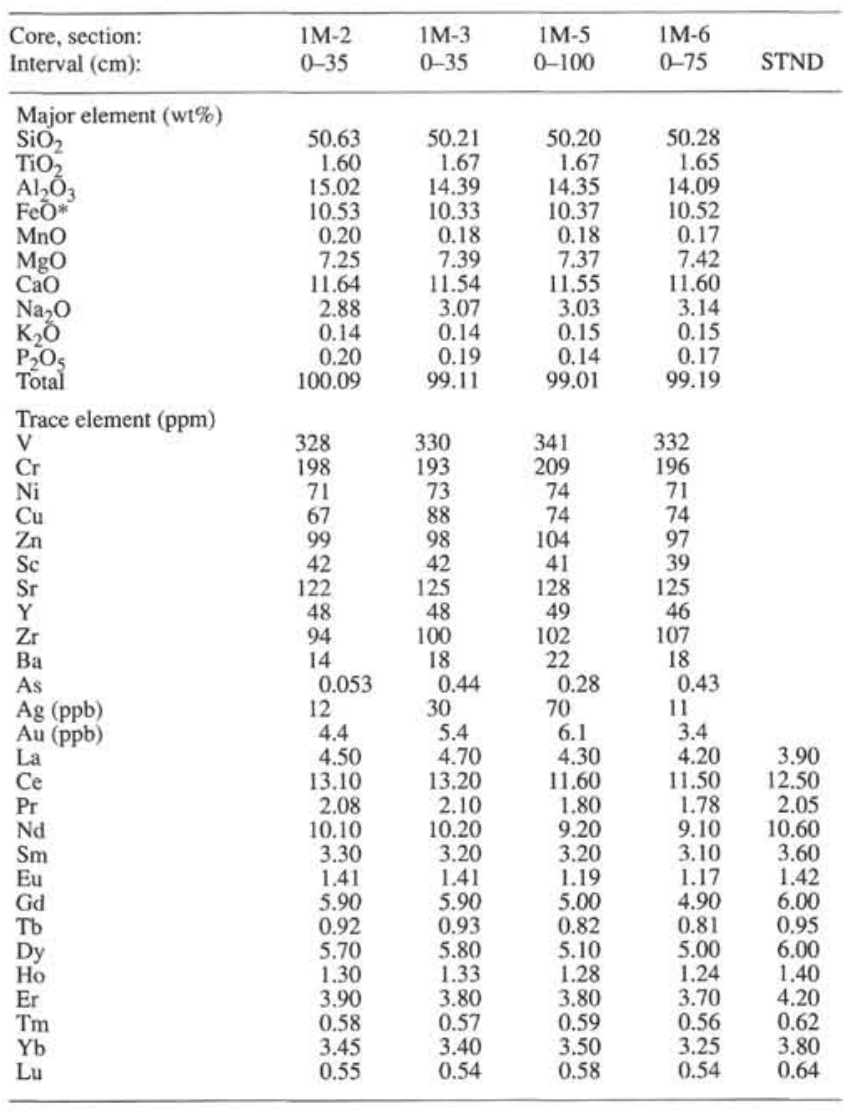

Notes: $\mathrm{FeO}^{*}=$ total iron as FeO; STND = basalt $396 \mathrm{~B}-15-2,120-133 \mathrm{~cm}$ (this work).

A brief petrographic description of Unit 1 basalts is given in Table 1 . Units 1 and 2 are compositionally very similar. Rare earth element concentrations of basalts are given in Table 2 .

Compositions of four analyzed glasses are very similar (Table 3), indicating that corresponding lava flows have a common source.

The chemical analyses of rocks and glasses lying in the tholeiitic field on the alkali-silica diagram (Fig. 1) and in mid-ocean-ridge basalts (MORB) field on the AFM diagram (Fig. 2). REE distribution in basalts (Fig. 3) and the spidogram for glasses (Fig. 4) show that these rocks belong to the series of normal mid-ocean-ridge basalts (N-MORB).

\section{ACKNOWLEDGMENTS}

We thank the reviewers for useful critical remarks; S. Liapunov (neutron-activation analysis of basalts), N. Kononkova (chemical analysis of glasses), E. Sedykh, E. Andrianova (ICP AES), L. Ban-

Table 2. Rare earth element concentrations (ppm) of basalts from Site 864.

\begin{tabular}{|c|c|c|c|c|c|c|c|c|c|c|}
\hline Hole: & $864 \mathrm{~A}$ & $864 \mathrm{~A}$ & $864 \mathrm{~A}$ & $864 \mathrm{~A}$ & $864 \mathrm{~A}$ & $864 \mathrm{~A}$ & $864 \mathrm{~B}$ & $864 \mathrm{~A}$ & $864 A$ & \\
\hline Core, section: & $1 \mathrm{M}-3$ & $1 \mathrm{M}-3$ & $1 \mathrm{M}-5$ & $1 \mathrm{M}-6$ & $1 \mathrm{M}-4$ & $1 \mathrm{M}-2$ & $2 \mathrm{~W}-1$ & $5 Z-1$ & $4-\mathrm{Zl}$ & \\
\hline Interval $(\mathrm{cm})$ : & $0-35$ & $100-150$ & $0-100$ & $0-75$ & $0-9$ & $0-35$ & $16-18$ & $24-30$ & pic2 & STND \\
\hline $\mathrm{La}$ & 4.1 & 4.5 & 4.0 & 3.7 & 3.6 & 4.3 & 4.1 & 4.2 & 4.0 & 16 \\
\hline $\mathrm{Ce}$ & 12 & 12 & 11 & 11 & 11 & 11 & 12 & 12 & 11 & 40 \\
\hline $\mathrm{Nd}$ & 9.6 & 11 & 9.6 & 9.6 & 9.6 & 10 & 11 & 11 & 11 & 24 \\
\hline $\mathrm{Sm}$ & 3.5 & 4.0 & 3.7 & 3.5 & 3.4 & 3.8 & 3.9 & 4.0 & 3.8 & 6.0 \\
\hline $\mathrm{Eu}$ & 1.3 & 1.4 & 1.4 & 1.4 & 1.3 & 1.3 & 1.4 & 1.5 & 1.4 & 2.0 \\
\hline $\mathrm{Tb}$ & 0.96 & 1.0 & 0.95 & 1.1 & 0.89 & 1.0 & 0.90 & 1.1 & 0.92 & 1.0 \\
\hline $\mathrm{Yb}$ & 3.1 & 3.9 & 3.4 & 3.3 & 3.1 & 3.7 & 3.7 & 3.8 & 3.6 & 1.95 \\
\hline Lu & 0.46 & 0.57 & 0.51 & 0.51 & 0.47 & 0.54 & 0.58 & 0.57 & 0.54 & 0.28 \\
\hline
\end{tabular}

Note: STND = standard sample USGS BHVO-1 (this work). 
nikh (AAS ETA), and G. Kolesov (neutron-activation analysis of glasses).

\section{REFERENCES $*$}

Gladney, E.S., and Roelandts, I., 1988. 1987 compilation of elemental concentration data for USGS BHVO-1, MAG-1, QLO-1, RGM-1, SCo-1, SDC-1, SGR-1 and STM-1. Geostand. Newsl., 12:253-262.

Kirkpatrick, R.J., and Leg 46 Shipboard Scientific Party, 1979. Interlaboratory comparision of Leg 46 basalt standards. In Dmitriev, L., Heirtzler, J., et al., Init. Repts. DSDP, 46: Washington (U.S. Govt. Printing Office), 293-297.

Macdonald, G.A., 1968. Composition and origin of Hawaiian lavas. Contrib. Hawaii Inst. Geophys. Year., 477-552.

Melson, W.G., Byerly, G.R., Nelen, J.A., O'Hearn, T., Wright, T.L., and Vallier, T., 1977. A catalog of the major element chemistry of abyssal volcanic glasses. Smithsonian Contrib. Earth Sci., 19:31-60.

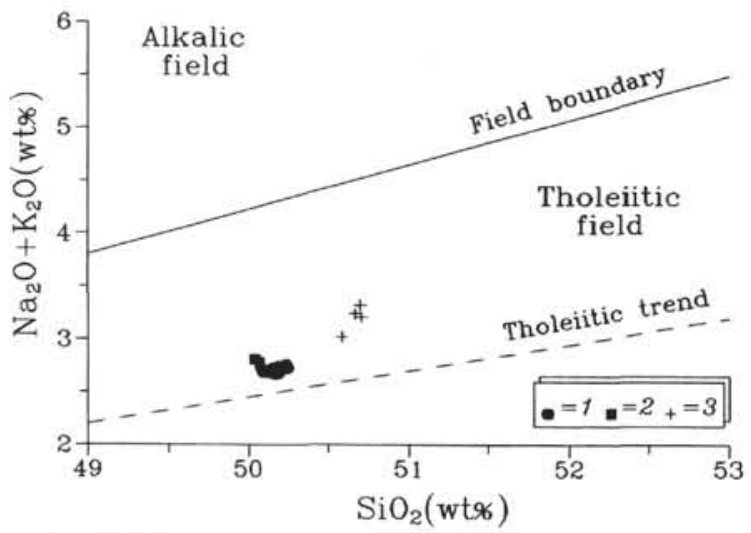

Figure 1. Alkali-silica variation diagram (Macdonald, 1968) of basalts and glasses from Site 864. 1 = Unit 1 basalts and glasses (Storms et al., 1993); 2 = Unit 2 basalts (Storms et al., 1993); 3 = new data on Unit 1 glasses .

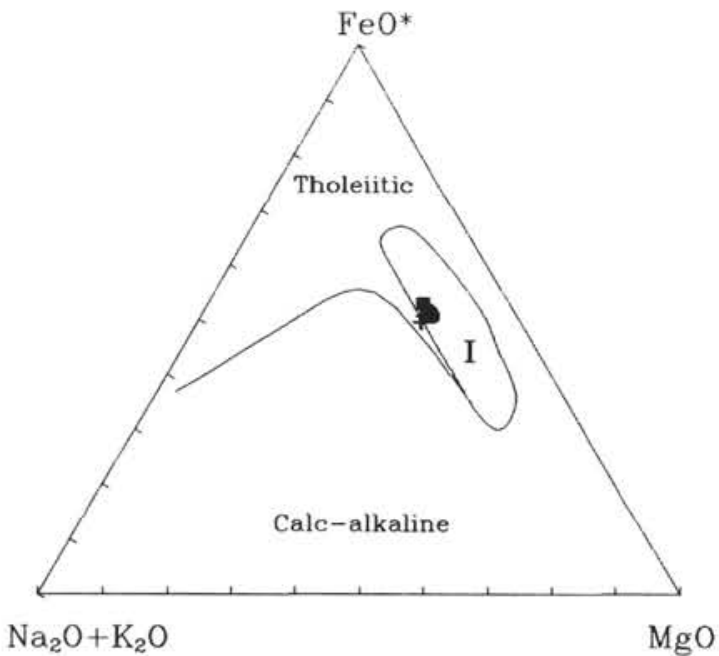

Figure 2. AFM diagram. $\mathrm{I}=$ MORB field. Symbols as in Figure 1.
Storms, M.A., Batiza, R., et al., 1993. Proc, ODP, Init. Repts., 142: College Station, TX (Ocean Drilling Program).

Sun, S.-S., and McDonough, W.F., 1989. Chemical and isotopic systematics of oceanic basalts: implications for mantle composition and processes. In Saunders, A.D., and Norry, M.J. (Eds.), Magmatism in the Ocean Basins. Geol. Soc. Spec. Publ. London, 42:313-345.

\section{Date of initial receipt: 30 September 1993}

Date of acceptance: 6 May 1994

Ms 142SR-114

-Abbreviations for names of organizations and publications in ODP reference lists follow the style given in Chemical Abstracts Service Source Index (published by American Chemical Society).

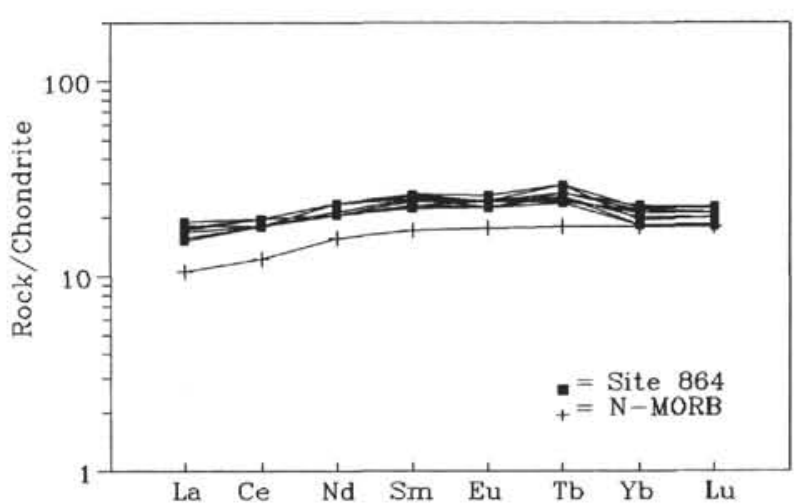

Figure 3. Rare earth elements of the basalts, normalized to chondrite. Average composition of N-MORB (Sun and MacDonough, 1989) is also plotted.

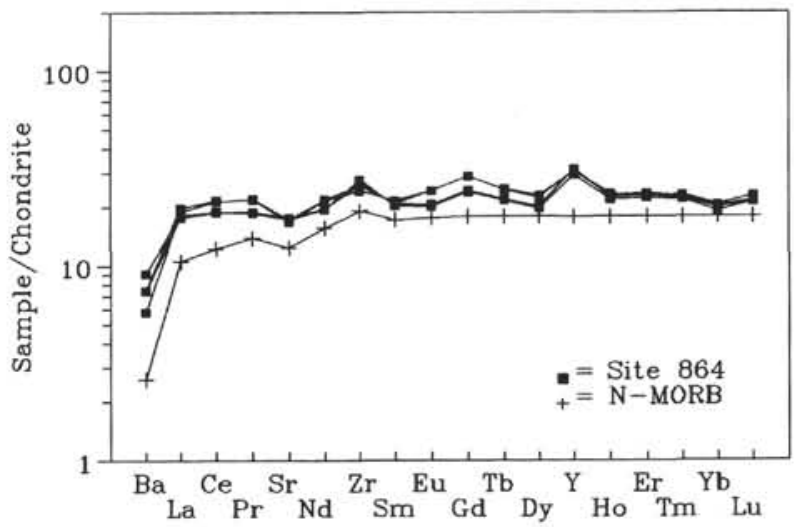

Figure 4. Trace elements of glasses (normalized to chondrite). Average composition of N-MORB (Sun and MacDonough, 1989) is also plotted. 